\title{
MODIFIKASI SELULOSA MENGGUNAKAN ASAM AKRILAT DAN TRIMETHALLYL ISOCIANURATE DENGAN METODE PRA IRADIASI PEROKSIDA
}

\author{
Meri Suhartini ${ }^{1}$, Asep Saefumillah ${ }^{2}$ dan Ikfa Nur Fadilla ${ }^{2}$ \\ ${ }^{1}$ Pusat Aplikasi Isotop dan Radiasi (PAIR) - BATAN \\ Jl. Lebak Bulus Raya No.49, Jakarta 12440 \\ ${ }^{2}$ Jurusan Kimia, FMIPA - UI \\ Kampus Baru UI, Depok 16424 \\ E-mail: meri@batan.go.id
}

Diterima: 14 Mei 2018

Diperbaiki: 18 Juli 2018

Disetujui: 13 Juli 2018

\begin{abstract}
ABSTRAK
MODIFIKASI SELULOSA MENGGUNAKAN ASAM AKRILAT DAN TRIMETHALLYL ISOCIANURATE DENGAN METODE PRA IRADIASI PEROKSIDA. Modifikasi selulosa dengan asam akrilat menggunakan pengikat silang Trimethallyl Isocianurate (TMAIC) dengan teknik kopolimerisasi cangkok pra-iradiasi-peroksida telah berhasil dilakukan. Penelitian ini bertujuan untuk mendapatkan adsorben ion logam berbasis selulosa. Pengikat silang TMAIC digunakan untuk meningkatkan ketahanan asam dan termal dari selulosa-g-AA. Kondisi optimum reaksi pencangkokan diperoleh pada dosis radiasi $40 \mathrm{kGy}$, konsentrasi TMAIC $0,5 \%(\mathrm{w} / \mathrm{v})$, konsentrasi monomer $10 \%(\mathrm{v} / \mathrm{v})$, suhu pencangkokan $90{ }^{\circ} \mathrm{C}$ dan waktu pencangkokan 6 jam, dengan persen pencangkokan rata-rata sebesar $42,37 \%$. Pengembangan dalam air turun sebesar $36 \%$ setelah penambahan TMAIC. Hasil sintesis kopolimer selulosa-TMAIC-g-AA telah berhasil dikarakterisasi dengan $F T-I R, T G A$ dan $S E M$. Selulosa terikat silang dapat digunakan sebagai adsorben ion logam $\mathrm{Pb}^{2+}$, dengan kapasitas adsorpsi sebesar $2,60 \mathrm{mg} / \mathrm{g}$ pada waktu kontak 2 jam dan $\mathrm{pH} 5$ (konsentrasi awal $\mathrm{Pb}^{2+} 10 \mathrm{mg} / \mathrm{L}$ ). Isoterm adsorpsi yang sesuai dengan adsorpsi $\mathrm{Pb}$ (II) dengan kopolimer adalah isoterm adsorpsi Langmuir yang berarti energi adsorpsi konstan di semua sisi kopolimer tersebut.
\end{abstract}

Kata kunci: Selulosa, Kopolimerisasi cangkok, Peroksida, Asam akrilat, Trimethallyl Isocianurate

\begin{abstract}
MODIFICATION OF CELLULOSE WITH ACRYLIC ACID AND TRIMETHALLYL ISOCIANURATE USING PRE IRRADIATION PEROXIDE METHOD. Modification of cellulose with acrylic acid monomers using Trimethallyl Isocianurate (TMAIC) as crosslinker by mean of pre irradiation graft copolymerization technique have been successfully carried out. This research aims to produce a cellulose base material which has metal ion adsorbent properties. TMAIC as crosslinking agent can be used to improve the chemical and thermal resistance of cellulose-g-AA. The optimum condition for graft copolymerization is obtained at $40 \mathrm{kGy}$ radiation dose, $0,5 \%$ (w/v) TMAIC, $10 \%(\mathrm{v} / \mathrm{v})$ monomer, $90^{\circ} \mathrm{C}$ grafting temperature and 6 hours reaction time, with $42,37 \%$ grafting average. The decreasing in swelling ratio in water is $36 \%$. Synthesized copolymers cellulose-TMAIC-g-AA was successfully characterized by FT-IR, TGA and SEM. Crosslinked cellulose-TMAIC-g-AA can be used as $\mathrm{Pb}^{2+}$ metal adsorbent, having adsorption capacity of $2,60 \mathrm{mg} / \mathrm{g}$ at 2 hours of contact time and $\mathrm{pH} 5$ (initial concentration of $\mathrm{Pb}^{2+} 10 \mathrm{mg} / \mathrm{L}$ ). Adsorption isotherms in accordance with the adsorption of $\mathrm{Pb}$ (II) by copolymer is Langmuir adsorption isotherm with mean constant energy adsoption in all side of the copolymer.
\end{abstract}

Keywords: Cellulose, Graft copolymerization, Peroxide, Acrylic acid, Trimethallyl Isocianurat 


\section{PENDAHULUAN}

Selulosa adalah polisakarida dan berat molekul tergantung pada sumber selulosa tersebut serta kondisi dan teknik isolasinya [1]. Teknik kopolimerisasi cangkok telah dimanfaatkan antara lain untuk mengubah sifat polimer induk dengan berbagai tujuan antara lain sebagai adsorben ion logam [2,3]. Dalam kopolimerisasi cangkok, rantai samping cangkok dengan kelompok fungsional kovalen melekat pada rantai utama dari backbone polimer untuk membentuk kopolimer bercabang [4].

Dengan mengkopolimerisasi cangkok Asam Akrilat (AA) ke suatu polimer selulosa menggunakan sinar gamma, komponen poliasam akrilat dalam rantai kopolimerisasi cangkok diharapkan dapat dimanfaatkan untuk memasukkan berbagai fungsi ke dalam selulosa melalui gugus karboksil yang dimilikinya. Selulosa terkopolimerisasi cangkok AA yang diperoleh dengan metode radiasi gamma ini akan ditambahkan dengan Trimethallyl Isocianurate (TMAIC) berbagai variasi untuk diketahui kondisi optimumnya, selanjutnya diuji absorbsi logam terhadap logam timbal.

TMAIC merupakan monomer yang memiliki beberapa gugus fungsi. Pada penelitian sebelumnya, mengenai modifikasi polimer biodegradabel dengan teknik radiasi pengikat silang menggunakan monomer polifungsional, keberadaan TMAIC dapat meningkatkan pengikatan silang radiasi Poly(e-Caprolactone) ( $P C L)$ and Poly(Butylene Succinate-Co-Adipate) (PBSA) yang diinisiasi oleh radiasi berkas elektron. Penelitian tersebut menunjukkan bahwa hasil optimum dari fraksi gel dapat dicapai ketika polimer diiradiasi dengan dosis $50 \mathrm{kGy}$ dengan adanya $1 \%$ TMAIC. Fraksi gel yang tinggi terutama meningkatkan stabilitas panas PBSA [5].

Pada penelitian kestabilan panas bionole hasil radiasi pengikatan silang, keberadaan TMAIC berperan sebagai aditif pengikat silang pada iradiasi Poli (butilen suksinat-co-adipat). Terbentuknya pengikatan silang dari PBS terbukti dapat meningkatkan kestabilan panas.[5]

Selulosa yang digunakan merupakan selulosa yang berasal dari jerami padi. [2] Jerami padi mengandung komponen selulosa 35,06\%, hemiselulosa 17,98 \% dan lignin $15,28 \%$. Selulosa jerami merupakan polimer yang tersusun atas monomer-monomer gula. [6]

Modifikasi polimer dengan teknik kopolimerisasi cangkok melibatkan pembentukan situs aktif berupa radikal bebas atau ion terlebih dahulu pada polimer induk. Pembentukan situs aktif pada polimer induk dapat dilakukan dengan dua cara, yakni metode kimia dan metode fisika. Pada metode kimia, radikal terbentuk pada selulosa akibat abstraksi atom hidrogen oleh radikal inisiator seperti Dibenzoyl Peroxide (BPO), Azoisisobutyronitrile (AIBN), atau bahan pengoksidasi garam cerium [7-9]. Diperoleh derajat grafting maksimum $87 \%$ pada pencangkokan asam akrilat pada selulosa dengan teknik prairadiasi, pada suhu $60{ }^{\circ} \mathrm{C}$ selama 6 jam, menggunakan sistem vacuum dan gas nitrogen, tanpa agent pengikat silang [2]. Pada pencangkokan asam akrilat menggunakan metode simultan dengan penambahan metilmetakrilat didapat kopolimerisasi, homopolimer, mengurangi swelling dan pengikatan silang [10]. Keberadaan homopolimer tidak dikehendaki pada pencangkokan untuk aplikasi sebagai adsorben.

Pada penelitian ini, electron beam digunakan sebagai inisiator yang diharapkan dapat membentuk intermediet aktif yang lebih merata pada kerangka polimer yaitu selulosa, sehingga dapat lebih mudah berikatan dengan pengikat silang TMAIC, selanjutnya dengan pemanasan pada reaksi dengan monomer asam akrilat dihasilkan polimer cangkok. Melalui variasi pengikat silang, variasi monomer, dosis radiasi, variasi waktu pencangkokan akan didapatkan kondisi operasi optimal untuk mendapatkan hasil reaksi pencangkokan yang optimum.

Diharapkan pengikat silang TMAIC dapat dipergunakan pada kopolimerisasi cangkok monomer asam akrilat pada selulosa dengan metode pra iradiasi peroksida menggunakan sinar berkas elektron. Keberhasilan metode pra iradiasi peroksida dapat menghilangkan penggunaan nitrogen gas pada proses pencangkokan secara pra iradiasi. Hasil pencangkokan akan di aplikasikan pada ion logam $\mathrm{Pb}$ (II). Keberhasilan penggunaan metode pra iradiasi dan peroksida pada pencangkokan monomer asam akrilat pada selulosa, diharapkan dapat meniadakan penggunaan gas Nitrogen yang selalu digunakan pada proses pencangkokan menggunakan metode pra iradiasi vacum.

\section{METODE PERCOBAAN}

\section{Bahan dan Alat}

Alat yang digunakan adalah gelas beaker, oven, Fourier Transform Infra Red (FT-IR), Thermogravimetric Analysis (TGA) Shimadzu DTG-60, Atomic Absorption Spectroscopy (AAS) Shimadzu AA-6800, Mesin berkas elektron $2 \mathrm{MeV}$. Bahan yang digunakan adalah selulosa dari jerami padi yang dibuat di PAIR-BATAN, asam akrilat (Merck Co) dan TMAIC (Trimetalil Isosianurat).

Peralatan yang digunakan dalam penelitian antara lain Mesin Berkas Elektron $2 \mathrm{MeV}$ untuk iradiasi selulosa, tabung polimerisasi, kondensor, penangas air, Spektrometer IR Prestige 21 Shimadzu, DTG-60 AH Shimadzu, AAS Shimadzu AA 6800, SEM tipe evo MA 10 Zeiss, peralatan gelas (beaker glass, pipet ukur, Labu ukur), pH-meter, Oven dan shaker.

\section{Persiapan Radiasi Selulosa dan TMAIC}

Lembar selulosa yang dibuat di PAIR-BATAN [2] dipotong dengan ukuran $\pm\left(\begin{array}{l}1 \\ \mathrm{x}\end{array} 2\right) \mathrm{cm}^{2}$ lalu memasukkan ke dalam plastik tahan radiasi. TMAIC 
dengan variasi konsentrasi 0,1\%(v/v); 0,5\%(v/v); dan $1 \%(\mathrm{v} / \mathrm{v})$, dimasukan pada selulosa. Selulosa-TMAIC diletakkan di atas loyang yang di bawahnya sudah diisi es batu lalu diiradiasi menggunakan mesin berkas elektron, $5 \mathrm{MeV}, 2 \mathrm{~mA}$ dengan dosis iradiasi $20 \mathrm{kGy}$, 30 kGy, 40 kGy, 60 kGy, 80 kGy, dan 100 kGy.[10] Sampel kemudian dicangkok dengan asam akrilat (konsentrasi $3 \%, 5 \%, 10 \%$ dan $20 \%$ ) pada suhu $50{ }^{\circ} \mathrm{C}, 70{ }^{\circ} \mathrm{C}, 90^{\circ} \mathrm{C}$, $100{ }^{\circ} \mathrm{C}$. Setelah 6 jam, kopolimer seulosa-TMAIC-g-AA yang didapatkan kemudian dicuci dengan aquadest panas untuk menghilangkan poli(AA) yang tidak tercangkok pada selulosa-TMAIC.

\section{Karakterisasi Kopolimer Menggunakan FT-IR}

Karakterisasi dilakukan menggunakan FT-IR model Spektrometer IR Prestige 21 Shimadzu, yang terdapat di PAIR-BATAN.

\section{Karakterisai Kopolimer Menggunakan TGA}

Karakterisasi dilakukan menggunakan TGA model DTG-60 AH Shimadzu,yang terdapat di PAIR-BATAN.

\section{Karakterisai kopolimer Selulosa-TMAIC-g- AA dengan Analisis Morfologi SEM}

Karakterisasi dengan SEM menggunakan SEM model SEM tipe evo MA 10 Zeiss. Yang terdapat di Lab. Universitas Indonesia.

\section{HASIL DAN PEMBAHASAN}

\section{Pengaruh Dosis Radiasi Terhadap Hasil Pencangkokan}

Pada Gambar 1 terlihat peningkatan dosis radiasi menyebabkan meningkatnya persen pencangkokan. Peningkatan persen pencangkokan pada dosis hingga 40 kGy terjadi karena semakin banyaknya jumlah radikal bebas yang terbentuk pada kerangka selulosa-TMAIC, sementara pada dosis lebih tinggi dari $40 \mathrm{kGy}$, jumlah

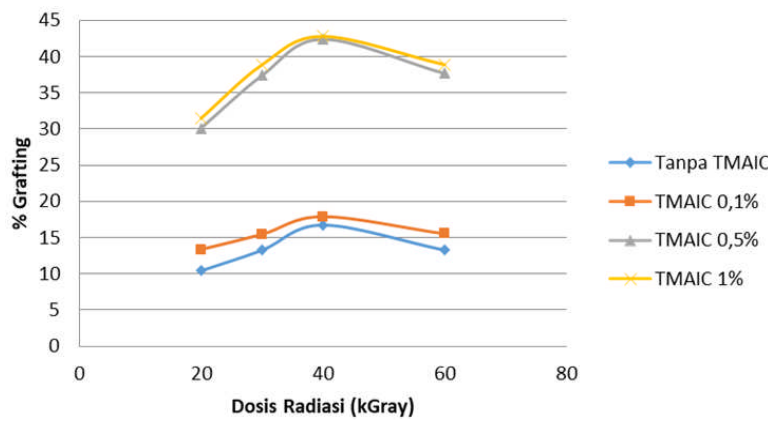

Gambar 1. Pengaruh dosis radiasi dan konsentrasi pengikat silang terhadap pencangkokan (monomer AA $10 \%$; suhu reaksi $90^{\circ} \mathrm{C}$; waktu pencangkokan 6 jam). radikal bebas yang semakin banyak menyebabkan probabilitas rekombinasi radikal dari selulosa-TMAIC semakin tinggi sehingga jumlah radikal yang digunakan untuk menginisiasi kopolimerisasi menjadi berkurang dan kemungkinan reaksi homopolimerisasi meningkat karena adanya transfer radikal ke molekul monomer. Selain itu, pada dosis yang tinggi dapat menyebabkan degradasi kerangka selulosa akibat reaksi pemutusan rantai, karena selulosa tergolong dalam kelas polimer terdegradasi dengan proses radiasi. Imbas radiasi pada reaksi radikal dalam polimer dapat memulai untuk chain scission (pengurangan berat molekul polimer) dan cross linking (peningkatan berat molekul polimer) [7]. Selama iradiasi, radikal selulosa terbentuk dengan lokalisasi elektron tak berpasangan pada posisi 1 dan 4 dari cincin piranosa. Proses yang terjadi adalah dehidrasi radikal membentuk ikatan rangkap dua dalam cincin piranosa yang menghasilkan radikal tipe allyl [11].

Dari Gambar 1 tersebut terlihat bahwa semakin tinggi konsentrasi pengikat silang TMAIC maka persen pencangkokan semakin meningkat. Pengikatan silang selulosa bertujuan untuk meningkatkan karakteristik termal, mekanik dan fisiko kimianya sesuai dengan yang dibutuhkan dalam penerapannya. TMAIC sebagai pengikat silang selulosa dan monomer AA karena setelah terikat dengan polimer selulosa, TMAIC masih mempunyai banyak tangan untuk mengikat monomer AA, karena itu TMAIC disebut Polifungsional Monomer, selain sebagai pengikat silang, dapat mencegah terjadinya degradasi pada selulosa karena selulosa terdegradasi dengan proses radiasi. Semakin banyak konsentrasi TMAIC maka semakin banyak monomer AA yang tercangkok pada selulosa-TMAIC dan menyebabkan meningkatnya pula persen pencangkokan. Pada konsentrasi TMAIC 0,1\% dan 0,5\% terlihat peningkatan persen pencangkokan, tetapi pada konsentrasi $0,5 \%$ dan $1 \%$ terlihat peningkatan persen pencangkokan yang tidak signifikan yang menandakan bahwa pada konsetrasi TMAIC 0,5\% merupakan persen pencangkokan tertinggi yaitu sebesar $42,37 \%$.

\section{Pengaruh Konsentrasi Monomer Asam Akrilat Terhadap Hasil Pencangkokan}

Selulosa mempunyai sifat hidrofilik yang artinya tidak larut dalam larutan air walaupun sifatnya yang hidrofilik, selulosa dapat mengembang dalam air karena selulosa merupakan molekul besar yang berserat sehingga monomer yang larut dalam air seperti asam akrilat, akrilamida dan derivatnya dapat berdifusi ke rantai polimer utama [9]. Dalam penelitian ini, dilakukan percobaan variasi konsetrasi monomer. Pada reaksi kopolimerisasi cangkok, pelarut merupakan pembawa monomer ke kerangka polimer. Pemilihan pelarut bergantung pada beberapa parameter diantaranya kelarutan monomer dalam pelarut, sifat swelling kerangka polimer, dan pembentukan radikal bebas dengan 
adanya pelarut. Pada percobaan digunakan pelarut air karena air dapat menyebabkan swelling selulosa secara efektif, sehingga memudahkan difusi monomer ke dalam struktur selulosa.

Pengaruh konsentrasi monomer asam akrilat dipelajari pada rentang konsentrasi $3 \% \mathrm{v} / \mathrm{v}$ hingga $20 \% \mathrm{v} / \mathrm{v}$, dengan konsentrasi TMAIC 0,5\%w/v, dosis radiasi $40 \mathrm{kGy}$, suhu reaksi $90^{\circ} \mathrm{C}$ dan waktu kopolimerisasi 6 jam. Hasil yang diperoleh ditunjukkan pada Gambar 2.

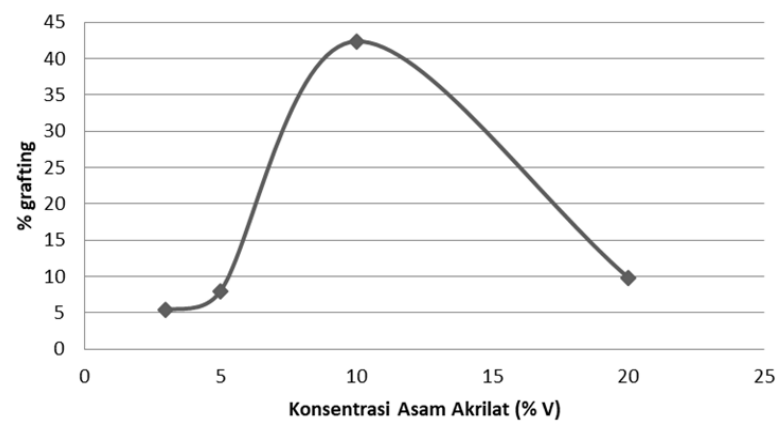

Gambar 2. Pengaruh konsentrasi monomer terhadap hasil pencangkokan (TMAIC 0,5\%, dosis radiasi $40 \mathrm{kGy}$; suhu reaksi $90^{\circ} \mathrm{C}$; waktu reaksi 6 jam).

Teknik kopolimerisasi yang digunakan dalam penelitian ini adalah teknik preiradiasi tanpa oksigen, menghilangkan oksigen pada penelitian ini dengan cara memvakum plastik yang telah berisi selulosa-TMAIC siap radiasi. Oksigen merupakan radical scavenger yang dapat menon-aktifkan radikal bebas (situs aktif) yang telah terbentuk sehingga menghambat terjadinya kopolimerisasi cangkok [9]. Peningkatan suhu akan meningkatkan energi dinamik molekul monomer yang akan meningkatkan difusi molekul monomer ke dalam kerangka polimer, diketahui bahwa di dalam aquadest panas yang merupakan pelarut polar, poli(AA) akan larut [9]. Kopolimer selulosa-TMAIC-g-AA yang diperoleh masih berbentuk lembaran seperti selulosa mula-mula, tetapi kopolimer ini telah mengalami swelling (pengembangan) ditandai dengan bertambahnya ketebalan dan bobot kopolimer seulosaTMAIC-g-AA. Konsentrasi dari monomer memberi pengaruh terhadap persen pencangkokan yang didapat karena berkaitan dengan kecepatan perpanjangan rantai homopolimer.

Dalam Gambar 2 dapat dilihat bahwa persen pencangkokan meningkat seiring dengan bertambahnya konsentrasi monomer. Pada konsentrasi monomer $3 \%$ dan $5 \%$, persen pencangkokan meningkat tetapi tidak signifikan karena ketika konsentrasi monomer kecil intensitas tumbukan yang terjadi antar molekul monomer AA juga kecil, sehingga laju propagasi rantai AA radikal menjadi lambat, akibatnya rantai AA yang tercangkok pada selulosa-TMAIC menjadi lambat. Konsentrasi monomer $10 \%$, merupakan konsentrasi optimum dengan persen pencangkokan tertinggi yaitu sebesar $42,37 \%$.
Hal ini disebabkan ketika konsentrasi monomer yang semakin tinggi, kecepatan rantai AA tercangkok pada selulosa-TMAIC akan semakin meningkat yang artinya meningkatnya difusi monomer ke dalam matriks selulosa sehingga probabilitas tumbukan antara molekul monomer AA dan selulosa-TMAIC semakin banyak yang menyebabkan persen pencangkokan meningkat.

Pada konsentrasi monomer AA $20 \%$ terjadi penurunan persen pencangkokan karena konsentrasi monomer yang terlalu tinggi mengakibatkan pembentukan rantai homopolimer poli(AA) radikal yang terlalu panjang, akibatnya rantai AA akan susah bergabung dengan sisi aktif pada polimer induk selulosa-TMAIC karena pergerakan monomer yang lambat, sehingga hanya sebagian kecil AA yang tercangkok pada selulosa-TMAIC. Konsentrasi monomer yang rendah mengurangi terbentuknya homopolimer tetapi difusi monomer kedalam matriks polimer juga rendah. Akan tetapi konsentrasi monomer yang terlalu tinggi akan menyebabkan terbentuknya homopolimer yang akan menghalangi terjadinya pencangkokan [11].

\section{Pengaruh Suhu Terhadap Hasil Pencangkokan}

Pada Gambar 3 dapat dilihat bahwa persen pencangkokan meningkat seiring dengan bertambahnya suhu proses pencangkokan, dan maksimum pada suhu $90{ }^{\circ} \mathrm{C}$ yang kemudian menurun pada suhu $100^{\circ} \mathrm{C}$, hal ini disebabkan menguapanya monomer asam akrilat pada suhu didih air tersebut.

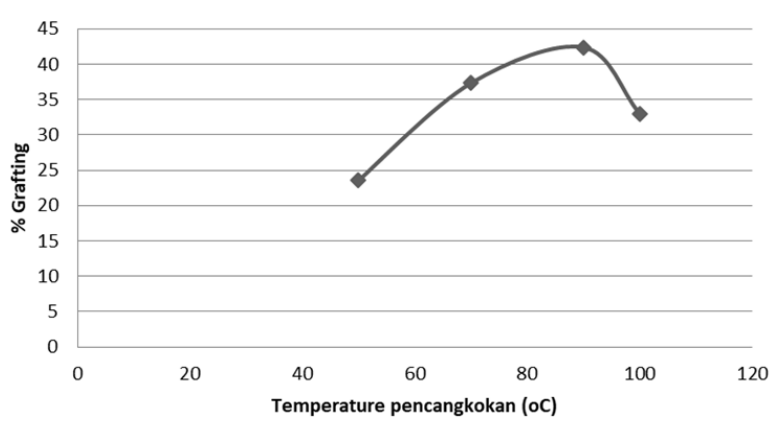

Gambar 3. Pengaruh suhu reaksi pencangkokan terhadap hasil pencangkokan (TMAIC 0,5\%, dosis radiasi $40 \mathrm{kGy}$; monomer AA $10 \%$; waktu reaksi 6 jam).

\section{Pengaruh Waktu Reaksi Kopolimerisasi terhadap Prosentase Pencangkokan}

Dari Gambar 4 dapat dilihat bahwa semakin lama waktu pencangkokan, maka semakin besar hasil pencangkokan yang didapatkan. Pada waktu reaksi 3 jam hingga 5 jam menunjukan peningkatan persen pencangkokan yang tidak terlalu besar, hal ini disebabkan pada waktu reaksi yang cukup singkat, kurang memberikan keleluasaan terhadap radikal-radikal pada TMAIC mengikat monomer AA dan sebagai pengikat silang antara polimer induk selulosa dan monomer AA. 
Modifikasi Selulosa Menggunakan Asam Akrilat dan Trimethallyl Isocianurate dengan Metode Pra Iradiasi Peroksida (Meri Suhartini)

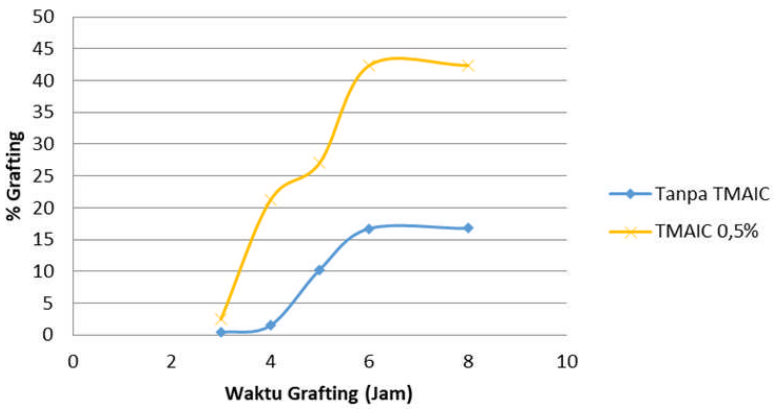

Gambar 4. Pengaruh waktu reaksi pencangkokan terhadap hasil pencangkokan (dosis radiasi $40 \mathrm{kGy}$; monomer AA $10 \%$; suhu reaksi $90^{\circ} \mathrm{C}$ )

Selain itu, kurang memberikan keleluasaan pada monomer AA untuk memperpanjang rantai homopolimernya dan keleluasaan radikal $\mathrm{OH}$ dalam menginisiasi pembentukan situs aktif pada selulosa-TMAIC, akibatnya rantai homopolimer poli(AA) yang terbentuk masih pendek dan jumlah situs aktif yang terdapat pada selulosa-TMAIC sedikit, sehingga jumlah poli(AA) yang tercangkok pada selulosa-TMAIC sedikit. Selain itu, pendeknya rantai poli(AA) yang tercangkok pada selulosa-TMAIC juga menyebabkan rendahnya persen pencangkokan.

Pada waktu reaksi 6 jam, terjadi peningkatan persen pencangkokan yang signifikan, menjadi sebesar $42,37 \%$. Hal ini terjadi karena waktu pencangkokan yang diberikan cukup lama sehingga memberikan keleluasaan terhadap radikal AA untuk memperpanjang rantai homopolimernya serta keleluasaan terhadap pembentukan situs aktif pada selulosa-TMAIC. Untuk itu, jumlah AA rantai panjang yang tercangkok pada selulosa-TMAIC semakin banyak.

Pada waktu 8 jam, penambahan waktu ini tidak menyebabkan perubahan persen pencangkokan yang signifikan. kurva yang terbentuk semakin datar bila dibandingkan dengan waktu pencangkokan sebelumnya hal ini terjadi karena kecepatan propagasi rantai poli(AA) menurun, jumlah situs aktif pada poli(AA) dan selulosa-TMAIC sedikit dan pada akhirnya proses kopolimerisasi pencangkokan mengalami terminasi. Mekanisme reaksi yang terjadi sesuai Persamaan (1) hingga Persamaan (3) [12].

$$
\begin{aligned}
P & \rightarrow P^{*}+M \rightarrow P^{*} \\
P+O_{2} & \hookrightarrow P O O H \text { atau } P O O P \\
& \rightarrow P^{*}+O^{*} \text { atau } 2 P^{*} \\
P O^{*}+O^{*} \text { atau } 2 P^{*},+M & \rightarrow P O M
\end{aligned}
$$

Dimana:

$$
\begin{aligned}
& \mathrm{P}=\text { Polimer } \\
& \mathrm{M}=\text { Monomer }
\end{aligned}
$$

TMAIC berfungsi sebagai pengikat silang pada selulosa dengan skemanya yang diperlihatkan pada Gambar 5 .

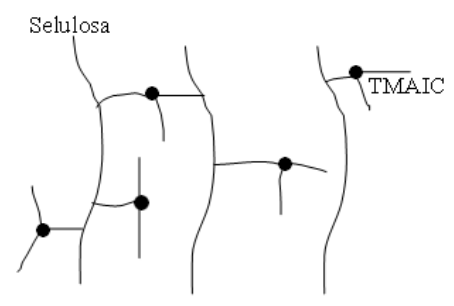

Gambar 5. Skema peran TMAIC sebagai pengikat silang pada selulosa.

\section{Karakterisasi Gugus Fungsi Kopolimer dengan FT-IR}

Spektrum infra merah selulosa-TMAIC-g-AA dibandingkan dengan selulosa murni menunjukkan adanya serapan baru pada bilangan gelombang $1700 \mathrm{~cm}^{-1}$ yang merupakan vibrasi regangan $-\mathrm{C}=\mathrm{O}$ dan pada bilangan gelombang $3400 \mathrm{~cm}^{-1}$ yang merupakan vibrasi regangan $\mathrm{O}-\mathrm{H}$.

Hal ini menjadi informasi tambahan untuk karbonil karboksilat karena absorpsi pada daerah $3400 \mathrm{~cm}^{-1}$ yang melebar tersebut yang disebabkan terjadi dimer atau ikatan hidrogen. Serapan baru ini menunjukkan bahwa karbonil karboksilat dari asam akrilat telah tercangkok pada rantai selulosa. Serapan pada $2900 \mathrm{~cm}^{-1}$ merupakan vibrasi regangan rantai alkana $\mathrm{C}-\mathrm{H}$ dari $\mathrm{CH}_{2}$. Serapan pada daerah $1120 \mathrm{~cm}^{-1}$ merupakan vibrasi dari ikatan eter $\mathrm{C}-\mathrm{O}$ yang menunjukkan bahwa terjadi ikatan antara gugus -O- dari selulosa dengan gugus -C- dari TMAIC. Serapan baru terjadi pada daerah $800 \mathrm{~cm}^{-1}$ merupakan vibrasi regangan $\mathrm{C}-\mathrm{N}$, ikatan $\mathrm{C}-\mathrm{N}$ ini terdapat di dalam senyawa TMAIC. Spektrum FT-IR ini menunjukkan perbedaan selulosa murni dan selulosa setelah

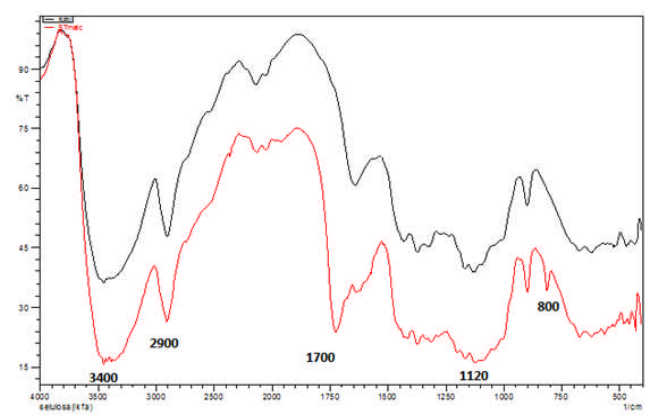

Gambar 6. Spektrum infra merah selulosa dan selulosaTMAIC-g-AA.

Cellulose

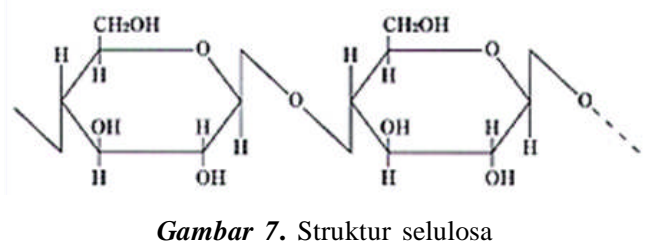


dicangkok dengan terdapatnya gugus-gugus baru dari TMAIC dan AA, seperti diperlihatkan pada Gambar 6.

Gambar 7 memperlihatkan struktur molekul dari selulosa dan Gambar 8 sruktru kopolimer selulosaTMAIC-g-AA

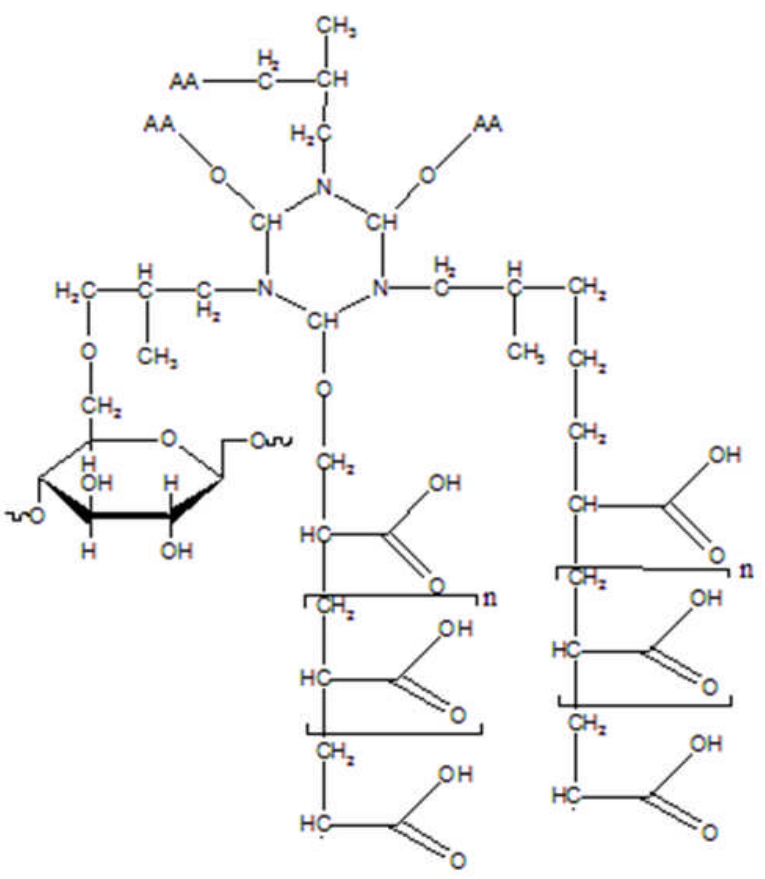

Gambar 8. Struktur Kopolimer Selulosa-TMAIC-g-AA

\section{Analisis Termal Kopolimer dengan TGA}

Analisis termal selulosa dan selulosa-TMAIC-gAA dilakukan dengan menggunakan $T G A$. Karakterisasi dengan menggunakan $T G A$ dilakukan untuk melihat stabilitas termal selulosa awal dan selulosa kopolimer. Berdasarkan Gambar 9 yang ditunjukkan dengan garis berwarna biru untuk kontrol yaitu selulosa awal dan garis coklat merupakan sampel yaitu selulosa-TMAIC-g-AA memiliki stabilitas termal yang hampir sama dan juga terlihat adanya beberapa tahap dekomposisi.

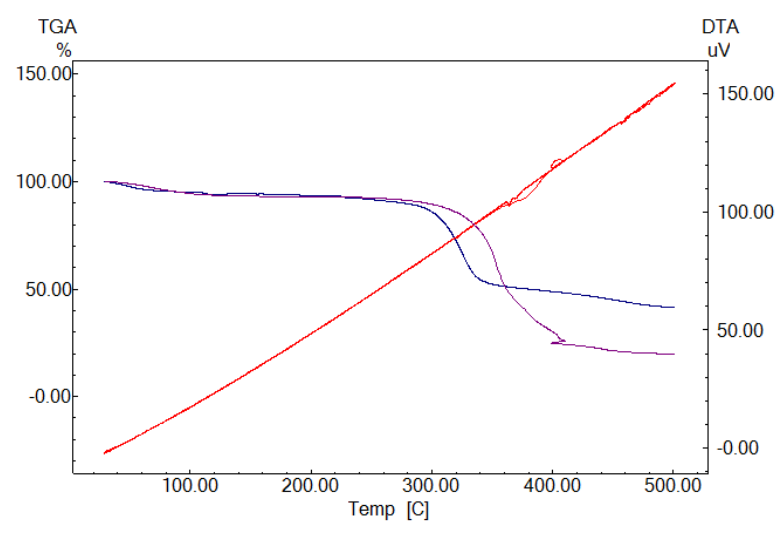

Gambar 9. Termogram Selulosa dan Selulosa-TMAIC-g-AA

Kedua sampel ditimbang dengan berat yang sama yaitu $12,5 \mathrm{mg}$. Kontrol pertama kali mulai terdekomposisi pada sekitar suhu $200{ }^{\circ} \mathrm{C}$ dan massa terdekomposisi sekitar $0,5 \mathrm{mg}$, sedangkan sampel pada sekitar suhu $60{ }^{\circ} \mathrm{C}$ dan terdekompoisi ekitar 0,5 mg. Kemungkinan komposisi keduanya berasal dari air yang masih ada di dalam selulosa.

Pada tahap kedua, kontrol mulai terdekomposisi pada sekitar suhu $280{ }^{\circ} \mathrm{C}$ dan massa sekitar $6 \mathrm{mg}$, sedangkan sampel pada sekitar suhu $320{ }^{\circ} \mathrm{C}$ dan massa sekitar $1 \mathrm{mg}$. Kemungkinan pada tahap ini, dekomposisi berasal dari jaringan ikatan silang polimer TMAIC-AA. Tahap selanjutnya, kontrol mulai terdekomposisi pada sekitar suhu $300{ }^{\circ} \mathrm{C}$ dengan massa sekitar $2,5 \mathrm{mg}$, sedangkan sampel pada suhu $340{ }^{\circ} \mathrm{C}$ dengan massa sekitar $7 \mathrm{mg}$. Tahap selanjutnya, kontrol mulai terdekomposisi pada sekitar suhu $390{ }^{\circ} \mathrm{C}$ dengan massa sekitar 0,5 mg, sedangkan sampel pada suhu $400{ }^{\circ} \mathrm{C}$ dengan massa sekitar $1 \mathrm{mg}$. Pada tahap terakhir, kontrol masih mengalami dekomposisi, pada sekitar suhu $400{ }^{\circ} \mathrm{C}$ dengan masa sekitar $0,5 \mathrm{mg}$, sedangkan sampel tidak mengalami dekomposisi lagi. Kemungkinan dekomposisi yang terjadi pada tahap terakhir ini berasal dari sisa-sisa komponen yang belum terdekomposisi pada suhu yang lebih rendah sehingga pada akhirnya kontrol menghasilkan sisa abu sebanyak 2,5 mg dan sampel menghasilkan sisa abu sebanyak $3 \mathrm{mg}$.

Berdasarkan hasil analisis dari termogram tersebut dapat diasumsikan bahwa TMAIC yang terdapat dalam sampel memberikan pengaruh yang besar terhadap stabilitas termal kopolimer, terlihat dari lamanya kopolimer sampel tersebut terdekomposisi, dibandingkan dengan selulosa murni, hal ini disebabkan oleh terbentuknya pengikatan silang dari selulosa-TMAIC-g-AA yang dapat meningkatkan kestabilan panas [5]. Modifikasi secara kimia merupakan solusi untuk meningkatkan kestabilan panas pada selulosa [13].

\section{Analisis Morfologi Kopolimer dengan SEM}

Karakterisasi morfologi permukaan selulosa dan selulosa-TMAIC-g-AA dilakukan menggunakan SEM. Hasil pengamatan mikrograf selulosa awal menunjukkan selulosa yang berbentuk serat dengan pori antar serat masih renggang seperti yang terdapat pada Gambar 10 . Pada hasil SEM selulosa-TMAIC-g-AA menunjukkan bahwa serat selulosa menebal dengan pori antar serat semakin rapat, hal ini dikarenakan monomer asam akrilat telah masuk ke dalam jaringan ikatan silang polimer selulosa dan TMAIC. Adanya pengikat silang TMAIC, membuat permukaan selulosa semakin rapat dan kuat.

\section{Rasio pengembangan Kopolimer Selulosa- TMAIC-g-AA}

Karakteristik utama material terikat silang adalah kemampuannya dalam mengadsorpsi pelarut dan menahannya tetap dalam struktur. Diantaranya swelling 
Modifikasi Selulosa Menggunakan Asam Akrilat dan Trimethallyl Isocianurate dengan Metode Pra Iradiasi Peroksida (Meri Suhartini)

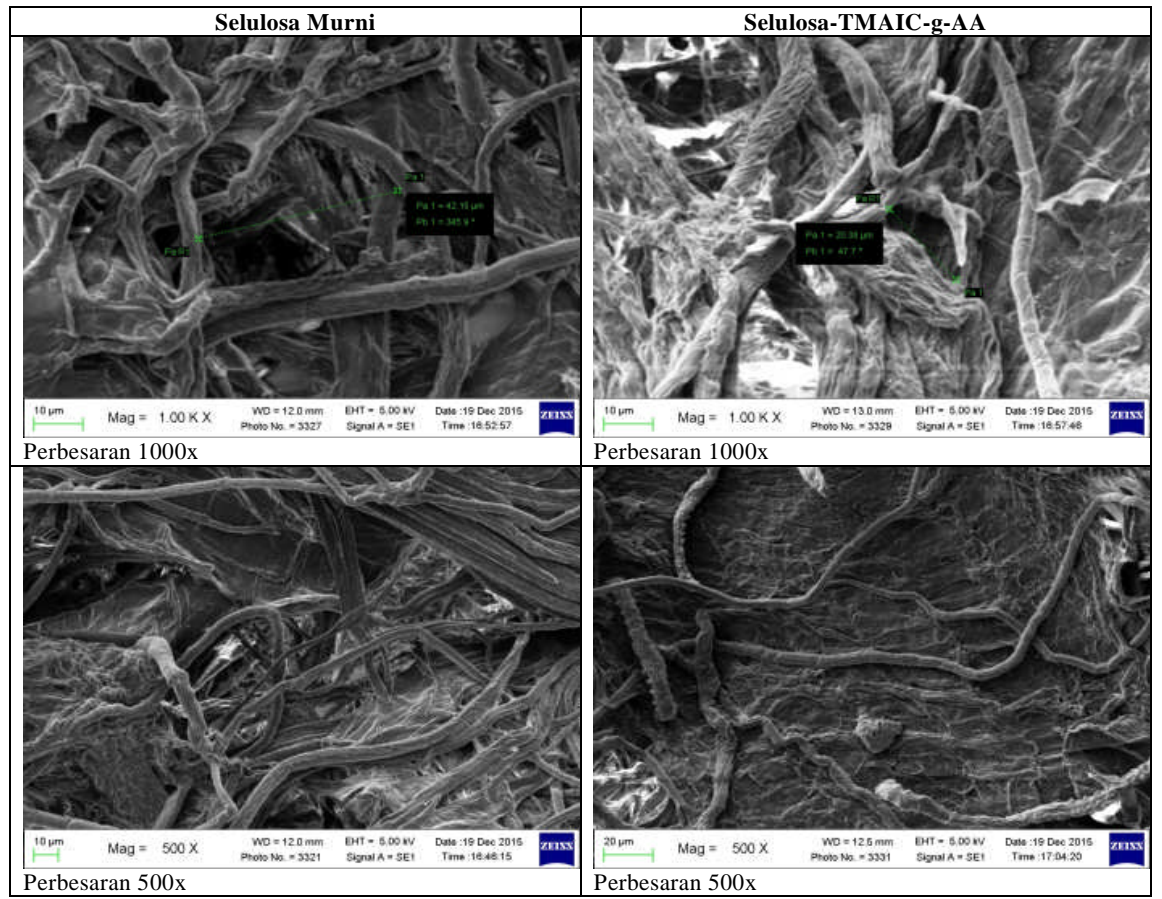

Gambar 10. Mikrograf Selulosa dan Selulosa-TMAIC-g-AA

yang bergantung pada hidrofilisitas polimer dan kerapatan ikatan antarmolekul. Adanya zat terlarut dengan berat molekul rendah, seperti garam-garam anorganik, dapat berpengaruh besar pada swelling. Daya serap air matriks selulosa-TMAIC tercangkok AA setelah direndam dalam akuades diperlihatkan pada Gambar 11, sebagai fungsi dari persen pencangkokan.

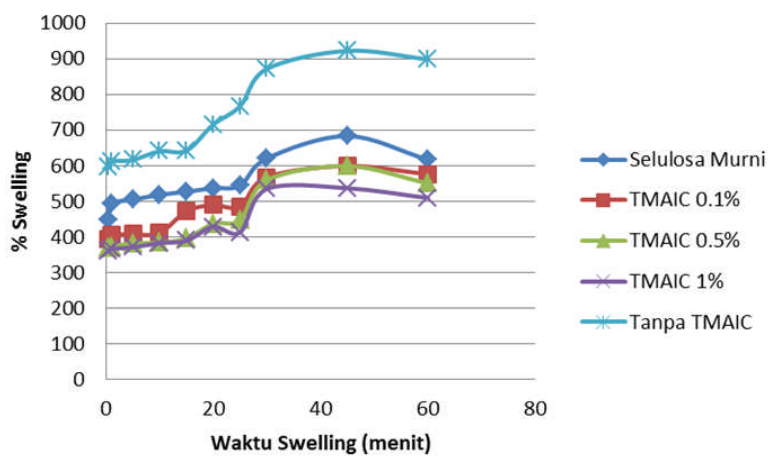

Gambar 11. Kurva rasio swelling terhadap waktu

Gambar 11 menunjukkan swelling selulosa terikat silang sebagai fungsi waktu swelling pada berbagai konsentrasi TMAIC. Pengikatan silang dilakukan menggunakan berkas elektron sebagai sumber radiasi, dan dilakukan sebelum pencangkokan monomer asam akrilat pada kerangka polimer selulosa.

Pada penelitian ini dipelajari pengaruh konsentrasi agent pengikat silang pada pembentukan fraksi terikat silang, serta karakteristik kimia dan termalnya. Pada Gambar 11 terlihat bahwa swelling tertinggi terjadi pada selulosa-AA tanpa TMAIC. Peningkatan fraksiikatan silang berkaitan erat dengan fraksi terikat silang, dimana semakin besar fraksi terikat silang, kerapatan molekul yang terbentuk semakin tinggi sehingga menghalangi kemampuan akses pelarut. Selulosa murni dan selulosa-g-AA memiliki persen swelling yang berbeda, hal ini berhubungan dengan struktur molekul dari gugus karboksilat yang terdapat pada matriks selulosa-g-AA yaitu gugus karboksil (R-COOH) yang berasal dari AA bertanggungjawab terhadap proses penyerapan air.

Hal ini disebabkan gugus karboksil memiliki kemampuan untuk mengikat molekul air dengan membentuk ikatan hidrogen antara gugus karboksil dengan molekul air. Semakin banyak gugus karboksil (R-COOH) yang terikat pada matriks, maka semakin banyak pula ikatan hidrogen yang terbentuk. Hal ini menyebabkan air yang terserap semakin banyak, sedangkan selulosa terikat silang yaitu selulosa-TMAIC-g-AA memiliki pengikatan silang mengurangi pengembangan selulosa di dalam air, karena sebagian gugus $\mathrm{OH}$ tersubstitusi oleh rantai pengikat silang, pengikat silang lebih memadatkan matriks sehingga ruang pada selulosa lebih kecil dan daya serap air menurun.

\section{Ketahanan Kopolimer Selulosa-TMAIC-g-AA terhadap Asam}

Hasil pengujian pada ketahanan terhadap asam ditunjukkan Tabel 1. Pada Tabel 1 terlihat bahwa setelah direndam $\mathrm{HCl} 2 \mathrm{~N}$ selama 2 jam, selulosa tanpa TMAIC atau selulosa-g-AA mengalami degradasi sebesar 15,66 \% atau lebih tinggi dibandingkan dengan degradasi selulosa murni sebesar $14,43 \%$. Hal ini menunjukkan pada selulosa-g-AA lebih banyak ikatan 
Table 1. Data \% degradasi sampel terhadap asam

\begin{tabular}{lc}
\hline \multicolumn{1}{c}{ Sampel } & \%Degradasi \\
\hline Selulosa Murni & 14,4295 \\
Tanpa TMAIC $(17,5 \%)$ & 15,6626 \\
$0,1 \%$ TMAIC $(19,27 \%)$ & 6,5116 \\
$0,5 \%$ TMAIC $(42,37 \%)$ & 4,5197 \\
$1 \%$ TMAIC $(42,77 \%)$ & 4,4313 \\
\hline
\end{tabular}

$\beta$-1,4-glikosida yang mudah diserang asam. Hal ini dapat terjadi karena dengan pencangkokan, akan terbentuk fasa amorf pada polimer akibat terjadinya ketidakteraturan struktur dibandingkan dengan selulosa awal.

Difusi larutan asam $(\mathrm{HCl})$ ke ikatan $\beta$-1,4-glikosida selulosa-g-AA menjadi lebih mudah ketika terbentuknya fasa amorf sehingga kemungkinan terjadinya reaksi hidrolisis meningkat. Berdasarkan pengamatan diperoleh bahwa selulosa terikat silang TMAIC 0,1\% mengalami degradasi sebesar $6,51 \%$, selulosa terikat silang TMAIC $0,5 \%$ mengalami degradasi sebesar $4,52 \%$, selulosa terikat silang TMAIC $1 \%$ mengalami degradasi sebesar $3,43 \%$, degradasi selulosa terikat silang menurun dibandingkan selulosa murni dan selulosa-g-AA. Terbentuknya ikatan silang pada selulosa menyebabkan kerapatan molekul yang terbentuk semakin tinggi sehingga dapat menghalangi penyerangan ikatan $\beta$-1,4-glikosida oleh asam, semakin tinggi konsentrasi ikatan silang, semakin tinggi pula kerapatan molekul yang terbentuk, dapat terlihat pada \% degradasinya.

Pada proses pengikatan silang, gugus $\mathrm{OH}$ and $\mathrm{CH}_{2} \mathrm{OH}$ mengalami reaksi kondensasi dengan melepaskan molekul air, menghasilkan jaringan tiga dimensi yang mengandung ikatan kovalen, karena itu ikatan $\beta$-1,4-glikosida relatif lebih tertutup hal ini menyebabkan matriks polimer terikat silang menjadi lebih tahan terhadap asam dan kerusakan selulosa dalam larutan asam merupakan reaksi hidrolisis ikatan $\beta$-1,4- glikosida, karena ikatan asetal tersebut tidak stabil dalam kondisi asam $[15,16]$.

\section{Analisis Kapasitas Adsorpsi terhadap Variasi Waktu Kontak}

Pengaruh waktu kontak adsorpsi terhadap kapasitas adsorpsi kopolimer dapat dilihat pada Gambar 12. Kapasitas adsorpsi terus meningkat hingga $1,40 \mathrm{mg} / \mathrm{g}$ adsorben pada menit ke 120 , kemudian turun pada menit ke 150 hingga $1,02 \mathrm{mg} / \mathrm{g}$. Hasil ini menunjukan bahwa kemampuan adsorpsi meningkat seiiring dengan meningkatnya waktu kontak adsorpsi, selanjutnya setelah melewati waktu optimum, kapasitas adsorpsi semakin turun.

Penurunan kapasitas adsorpsi setelah menit ke120 dimungkinan karena terjadi pelepasan kembali ikatan antara sisi aktif pada gugus karboksilat adsorben dengan ion $\mathrm{Pb}(\mathrm{II})$ atau desorpsi akibat semakin lamanya waktu kontak antara adsorben dan adsorbat karena adsorben telah jenuh oleh ion adsorbat.

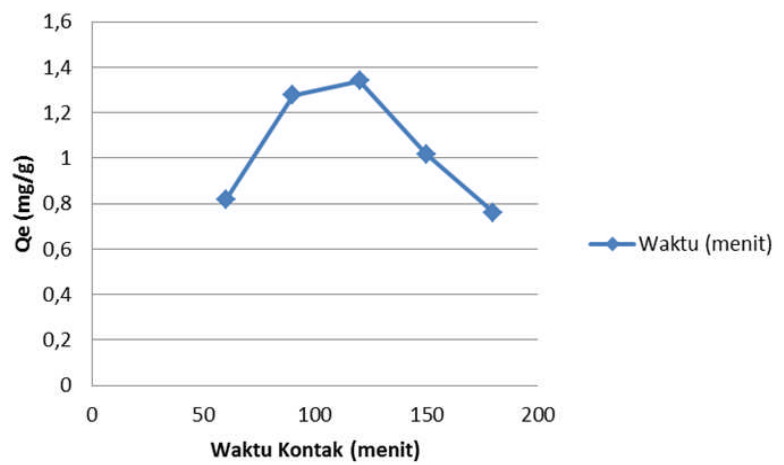

Gambar 12. Kurva pengaruh variasi waktu kontak terhadap kapasitas adsorpsi kopolimer.

\section{Analisis Kapasitas Adsorpsi terhadap Variasi $\mathrm{pH}$}

Pengaruh kondisi $\mathrm{pH}$ saat adsorpsi terhadap kapasitas adsorpsi kopolimer dapat dilihat pada Gambar 13. kapasitas adsorpsi terus meningkat hingga $2,60 \mathrm{mg} / \mathrm{g}$ adsorben pada $\mathrm{pH} 5$, kemudian turun pada pH 6 hingga 2,37 mg/g. Hasil analisis AAS diperoleh bahwa pada $\mathrm{pH} 3, \mathrm{pH} 4$ dan $\mathrm{pH}$ 5. Konsentrasi $\mathrm{Pb}^{2+}$ yang teradsorpsi meningkat seiring dengan peningkatan $\mathrm{pH}$.

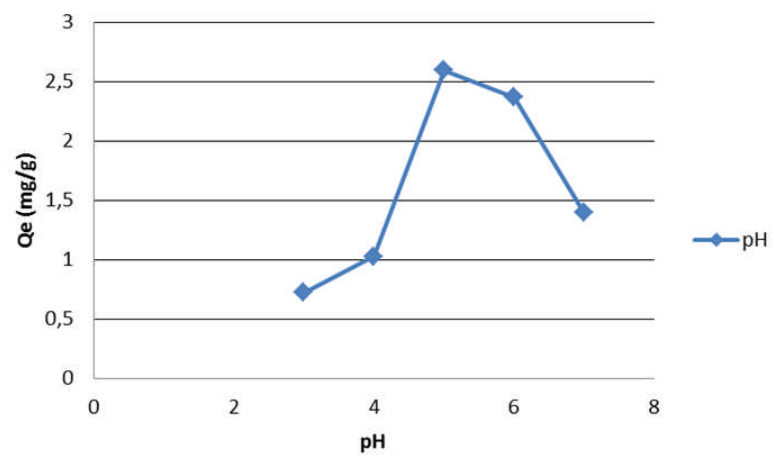

Gambar 13. Kurva pengaruh variasi $\mathrm{pH}$ terhadap kapasitas adsorpsi kopolimer

Hal ini terjadi dikarenakan semakin besar $\mathrm{pH}$ semakin besar gugus asam akrilat mengalami deprotonasi dan memiliki muatan negatif yaitu ion $\mathrm{OH}^{-}$yang sangat reaktif terhadap logam, sehingga logam yang teradsorpsi makin besar. Pada pH 6 dan pH 7 menunjukkan konsentrasi $\mathrm{Pb}^{2+}$ yang teradsorpsi menurun. Hal ini kemungkinan disebabkan karena konsentrasi pada keadaan ini terjadi kesetimbangan situs aktif kopolimer dengan ion logam dan pada $\mathrm{pH}$ tersebut mulai terjadi pengendapan garam ion logam $\mathrm{Pb}^{2+}$. Pada $\mathrm{pH}$ rendah permukaan adsorben akan dikelilingi oleh ion hidronium dengan konsentrasi tinggi, yang menyebabkan tolakan gaya elektrostatik yang lebih besar, keadaan ini menurunkan interaksi antara ion-ion logam dengan situs pengikat yang ada pada adsorben. Dengan naiknya $\mathrm{pH}$, permukaan adsorben secara keseluruhan menjadi negatif sehingga adsorpsi meningkat. Pada nilai $\mathrm{pH}$ 5, peningkatan kapasitas adsorpsi dapat disebabkan oleh dua mekanisme yaitu terjadinya garam komplek 
ion-exchange dari ion metal karena deprotonasited hydroksil pada amine grup pada selulosa adsorben dan mekanisme adsorpsi secara fisika.

\section{Analisis Kapasitas Adsorpsi Terhadap Variasi Konsentrasi Ion $\mathrm{Pb}$ (II) dan Isoterm Adsorpsi}

Fenomena adsorpsi digambarkan melalui Isoterm Adsorpsi yaitu suatu hubungan antara jumlah adsorbat yang terserap persatuan bobot adsorben dan konsentrasi kesetimbangan. Tipe isoterm yang digunakan oleh adsorpsi padat cair yaitu isoterm Freundlich dan Langmuir. Tipe isoterm adsorpsi ini dapat digunakan untuk mengetahui proses terbentuknya lapisan adsorbat pada permukaan adsorben dalam bentuk monolayer atau multilayer.

Pada analisis model Freundlich dilakukan dengan membuat persamaan garis linier antara Log Ce terhadap Log Qe, sedangkan pada analisis model Langmuir antara Ce terhadap Ce/qe. Hasil analisis ditunjukkan pada Gambar 14 dan Gambar15.

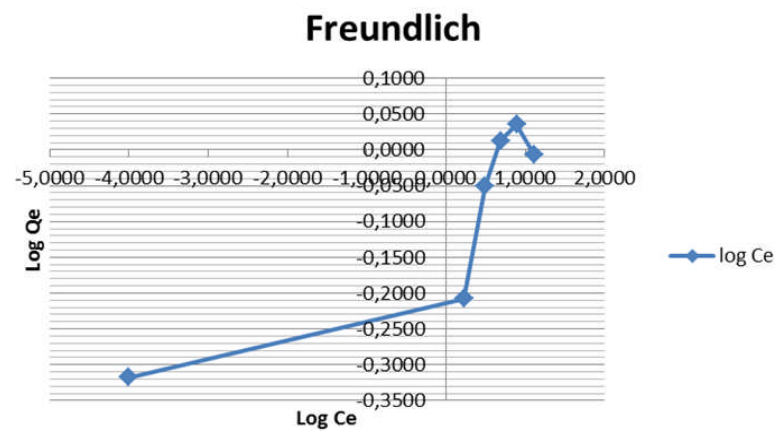

Gambar 14. Isoterm Freundlich adsopsi $\mathrm{Pb}$ (II) oleh kopolimer.

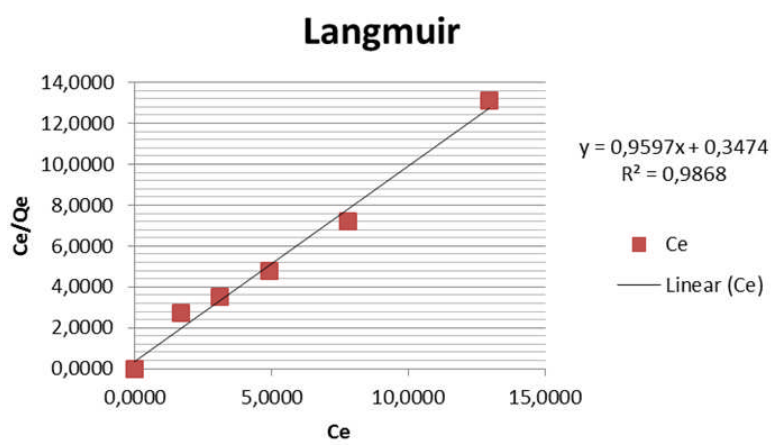

Gambar 15. Isoterm Langmuir adsopsi $\mathrm{Pb}(\mathrm{II})$ oleh kopolimer.

Bedasarkan hasil yang didapatkan, proses adsorpsi selulosa-TMAIC-g-AA pada semua variasi konsentrasi mengikuti isoterm Langmuir. Isoterm Langmuir mengasumsikan bahwa adsorbat yang teradsorpsi membentuk monolayer, yang artinya adsorben mempunyai permukaan yang homogen, energi adsorpsi konstan di semua sisi, dan semua proses adsorpsi sama rata di setiap permukaan adsorben.
Berdasarkan grafik, isoterm adsorpsi $\mathrm{Pb}(\mathrm{II})$ dengan kopolimer mengikuti isoterm adsorpsi Langmuir karena memiliki linieritas 0,9868 (Gambar 15), lebih tinggi dibandingkan dengan isoterm adsorpsi tipe Freundlich yaitu 0,737 (Gambar 14).

\section{KESIMPULAN}

Dari penelitian yang sudah dilakukan diperoleh kesimpulan sebagai berikut:

1. Teknik kopolimerisasi cangkok pra iradiasi peroksida dapat dipergunakan untuk mensintesis kopolimer cangkok Asam akrilat selulosa dengan keberadaan TMAIC.

2. Hasil optimal pencangkokan sebesar $42,37 \%$, diperoleh pada kondisi proses modifikasi pada dosis iradiasi $40 \mathrm{kGy}$, konsentrasi TMAIC 0,5\%, asam akrilat $10 \%$, waktu pencangkokan 6 jam dan suhu $90{ }^{\circ} \mathrm{C}$.

3. Pada observasi menggunakan FT-IR hasil kopolimerisasi cangkok selulosa dengan monomer asam akrilat, terdapat gugus $-\mathrm{C}=\mathrm{O}$ dan $\mathrm{O}-\mathrm{H}$. Hal ini menjadi informasi tambahan untuk karbonil karboksilat, juga terdapat rantai alkana $\mathrm{C}-\mathrm{H}$ dari $\mathrm{CH}_{2}$. Ikatan eter $\mathrm{C}-\mathrm{O}$ yang menunjukkan bahwa terjadi ikatan antara gugus -O- dari selulosa dengan gugus -C- dari TMAIC. Terdapat ikatan C-N, ikatan C-N ini terdapat di dalam senyawa TMAIC. Dari hasil karakterisasi menggunakan $F T$-IR menunjukkan bahwa metode pra iradiasi peroksida dapat dipergunakan untuk pencangkokan asam akrilat pada selulosa.

4. Hasil analisis menggunakan TGA, dari termogram dapat diasumsikan bahwa TMAIC yang terdapat dalam sampel memberikan pengaruh yang besar terhadap stabilitas termal kopolimer, yaitu meningkatkan kestabilan panas, karena terbentuknya ikatan silang dari selulosa-TMAIC-g-AA.

5. Isoterm adsorpsi $\mathrm{Pb}(\mathrm{II})$ dengan kopolimer mengikuti isoterm adsorpsi Langmuir karena memiliki linieritas 0,9868 .

6. Adsorpsi ion $\mathrm{Pb}(\mathrm{II})$ (sorbent awal $10 \mathrm{ppm}$ ), optimum $2,60 \mathrm{mg} / \mathrm{g}$ pada waktu kontak 120 menit dan $\mathrm{pH} 5$.

\section{DAFTAR ACUAN}

[1]. H. Kang, Liu R., and Y. Huang. "Graft Modification of Cellulose: Methods, Properties and Applications." Polymer, vol. 70, pp. A1-16, 2015.

[2]. Rahmawati, M. Suhartini, dan E. Budianto. "Radiation Graft Copolymerization of Acrylic Acid onto Rice Straw Cellulose". Macromol Symp, vol. 353, pp. 231-239, 2015.

[3]. T.S. Anirudhan, S.S. Sreekumari and S. Jalajamony. "An Investigation Into The Adsorption of Thorium(IV) from Aqueous Solutions by a Carboxylate-Functionalised Graft Copolymer 
Derived from Titanium Dioxide-Densified Cellulose". Journal of Environmental Radioactivity, vol.116, pp 141-147, 2013.

[4]. L. Zheng, Z. Dang, C. Zhu, X. Yi, H. Zhang and C. Liu. "Removal of Cadmium(II) from Aqueous Solution by Corn Stalk Graft Copolymers". Bioresource Technology, vol. 101, no. 15, pp. 5820-5826, 2010.

[5]. M. Suhartini dan S.Yusuf. "Kestabilan Panas Bionole Hasil Radiasi Pengikatan Silang". Jurnal Sains Materi Indonesia,vol.11, no.2, 2010.

[6]. Kodri, Bambang D.A., and Rini Y. "Pemanfaatan Enzim Selulase dari Trichorderma Reesei dan Aspergillus Niger untuk Enzymatic Hydrolisis Jerami Padi dengan Pretreatment Microwave". Jurnal Bioproses Komoditas Tropis, vol. 1, no. 1, 2013.

[7]. M. Suhartini, F. Yoshii, H. Mitomo and N. Nagasawa. "Radiation Yield and Radicals Produced in Irradiated Poly (Butylene Succinate)". Atom Indonesia, vol. 30, no. 1, 2004.

[8]. C. Routray and B. Tosh. "Graft Copolymerization of Methyl methacrylate (MMA) Onto Cellulose Acetate in Homogeneous medium: Effect of Solvent, Initiator and Homopolymer Inhibitor." Cellulose Chem.Technol., vol.47, no. 3-4, pp. 171-190, 2013.

[9]. J. F. Zhong, X.S. Chai and S.Y. Fu. "Homogeneous Grafting Poly(Methyl Methacrylate) on Cellulose by Atom Transfer Radical Polymerization." Carbohydrate Polymers, vol. 87, pp. 1869-1873, 2012.

[10]. M. Suhartini. "Pencangkokan Secara Radiasi Asam Akrilat Pada Selulosa Dengan Keberadaan Metil Metakrilat". Jurnal Iptek Nuklir Ganendra, vol.19, no.1,2016.
[11]. S.M. Sayyah, A. A. Essawy, and A.M. El-Nggar. "Kinetic Studies and Grafting Mechanism for Methyl Aniline Derivatives onto Chitosan: Highly Adsorptive Copolymers for Dye Removal from Aqueous Solutions". Reactive and Functional Polymers, vol 96, pp. 50-60, 2015.

[12]. A. Bhattacharya, B.N. Misra. "Grafting: A Versatile Means to Modify Polymers: Techniques, Factors and Applications". Prog. Polym. Sci., vol. 29, no. 8, pp. 767-814, 2004.

[13]. V. K. Thakura, M. K. Thakurb, and R. K. Gupta. "Rapid Synthesis of Graft Copolymers from Natural Cellulose Fibers". Carbohydrate Polymers, vol. 98, no. 1, pp. 820-828, 2013.

[14]. K. Zhang, L. Zong, Y. Tan, Q. Ji, W.Yun, R. Shi, and, Y. Xia. "Improve The Flame Retardancy of Cellulose Fibers by Grafting Zinc Ion". Carbohydrate Polymers, vol. 136, pp. 121-127, 2016.

[15]. G. S. Hutomo, A. Rahim and S. Kadir. "The Effect of Sulfuric and Hydrochloric Acid on Cellulose Degradation from Pod Husk Cacao". Int. J. Curr. Microbiol. App. Sci., vol. 4. no. 10, pp. 89-95, 2015.

[16]. W. Liu, Y. Liu, X. Hao, G. Zeng, W. Wang, R. Liu and Y.Huang. "Backbone-Collapsed Intra- and Inter-Molecular Self-Assembly of Cellulose-Based Dense Graft Copolymer". Carbohydrate Polymers, vol. 88, pp. 290-298, 2012.

[17]. A.A.Yakout, R. H. El-Sokkary, M.A. Shreadah, and O.G.A. Hamid. "Removal of $\mathrm{Cd}(\mathrm{II})$ and $\mathrm{Pb}$ (II) from Wastewater by Using Triethylenetetramine Functionalized Grafted CelluloseacetateManganese Dioxide Composite". Carbohydrate Polymers, vol. 148, pp. 406-414, 2016. 